\title{
THE FEDERAL INTERPLEADER ACT AND CON. FLICT OF LAWS IN GARNISHMENT
}

\author{
HAROLD WrIGHT HoLT*
}

I

RMOUR FERTILTZER WORKS, an Ilinois corporation, has a
claim against Sanders, a citizen and resident of Texas. It con-
templates an action at law to reduce this claim to judgment. Before bringing suit it makes an investigation to find out whether or not Sanders has any property on which it could levy an attachment or execution to satisfy a judgment. It finds that he has no tangible propertysuch as cattle, land, automobiles, etc.-subject to attachment or execution. It does discover, however, that the Garnishee Company, a corporation organized under the laws of Connecticut and lawfully transacting business in Illinois as well as in Connecticut, owes Sanders a simple contract debt. Sanders may have a valuable asset in this chose in action against the Garnishee Company. By assignment he could dispose of it for value. In short it is "property." In the absence of some prohibition imposed by some competent law some method should exist whereby Armour Fertilizer Works could compel the application of the proceeds of Sanders' claim against the Garnishee Company to the satisfaction of any judgment that Armour Fertilizer Works might recover against him. By legal process Armour Fertilizer Works should be able to collect directly the amount the Garnishee Company is adjudged to owe Sanders and apply such collection in partial or total satisfaction of the amount he is adjudged to owe Armour Fertilizer Works.

Conceivably the law might permit Armour Fertilizer Works to bring an action against Sanders in Texas, perhaps the only state in which a personal judgment could be recovered against him. Contemporaneously with the institution of this action, on the petition of Armour Fertilizer Works filed in Connecticut or Illinois against the Garnishee Company, the latter would be enjoined from paying its debt to Sanders pending the outcome of the Texas action. If Armour Fertilizer Works recovered judgment against Sanders in the Texas action, the Texas court would order such judgment satisfied out of the proceeds of the debt that the court in the Connecticut or Illinois suit might adjudge the Garnishee Company to owe

* Professor of Law, University of Illinois College of Law. 
Sanders. Armour Fertilizer Works would then proceed in the court of Connecticut or Illinois (in whichever of those states the second suit had been filed) to have the Garnishee Company adjudged a debtor to Sanders and to have the amount of such debt determined, to have payment of such debt ordered made into court and to have such payment applied on the Texas judgment theretofore recovered by Armour Fertilizer Works against Sanders.

Substitute France for Connecticut or Illinois in the foregoing case. Armour Fertilizer Works might accomplish its ends as indicated. A French court might enjoin payment of the debt due from the Garnishee Company to Sanders pending the outcome of the Texas action against him brought by Armour Fertilizer Works. If in that Texas action Armour Fertilizer Works were to recover a judgment against Sanders, the French court might then direct and compel payment of it to be made from the proceeds of the debt due from the Garnishee Company to Sanders. ${ }^{x}$

American law, however, has not developed a process like that just described and like that which seems to have been developed in France. In spite of any arguments that may be made in its favor, such process is awkward and cumbersome. Not unnaturally Armour Fertilizer Works wishes, if possible, in one suit to have Sanders adjudged to be its debtor and the Garnishee Company adjudged to be the debtor of Sanders. In this same suit Armour Fertilizer Works wishes to force the payment into court of the Garnishee Company's debt to Sanders in order to secure the satisfaction of its own judgment against Sanders.

Under some circumstances this may be done. For example, assume that Armour Fertilizer Works could secure personal service of process upon Sanders in Connecticut and that Connecticut permits an action by a nonresident corporation against a non-resident. The Garnishee Company, a Connecticut corporation, is subject to suit in that state. There is no doubt that Connecticut may then allow a suit by Armour Fertilizer Works against Sanders and the Garnishee Company for a twofold purpose: first, to reduce to judgment the claim of Armour Fertilizer Works against Sanders; secondly, to enforce satisfaction of such judgment out of the proceeds of the debt that the Garnishee Company is adjudged to owe Sanders. ${ }^{2}$ Such a suit is described as one in foreign attachment, garnishment

I See the account in Beale, The Exercise of Jurisdiction in Rem to Compel Payment of a Debt, 27 Harv. L. Rev. I07, I23 (I913). The author gives an account of Todesco v. Dumont, Civil Tribunal Seine, March 8, 1890 , I 8 Clunet 559 (I89o). An account of that case is also given in 1 Beale, Cases on the Conflict of Laws 339 (rg28).

= See Conn. Gen. Stat. I930, §§ 5763 et seq.; Parker, Peebles \& Knox v. El Saieh, xo7 Conn. 545, I4I Atl. 884 (I928). 
or trustee process. In this article one in the position of Armour Fertilizer Works will sometimes be designated as the principal creditor or garnishee creditor. One in the position of Sanders, who is both a debtor and a creditor, will at times be designated as the principal debtor or as the debtor-creditor, and one in the position of the Garnishee Company as the garnishee debtor or, simply, as the garnishee.

Return now to the state of facts in which Texas is the only state in which Armour Fertilizer Works can secure a judgment against Sanders on personal service. Assume that the Garnishee Company is not subject to suit in Texas. Armour Fertilizer Works brings an action in garnishment in Connecticut against Sanders and the Garnishee Company. Sanders is served only by publication. Personal service is had on the Garnishee Company as garnishee of the debt it owes Sanders. The Connecticut court finds that the Garnishee Company owes Sanders and that Sanders owes Armour Fertilizer Works. Because Connecticut is the state in which the Garnishee Company is incorporated, and because Sanders could have sued there on his claim, the Connecticut court can render a judgment against the Garnishee Company compelling it to pay the amount it has been so adjudged to owe Sanders into court for application, in whole or in part, in payment of the amount Sanders has been adjudged to owe Armour Fertilizer Works. ${ }^{3}$ It is immaterial that Sanders is not a citizen or resident of Connecticut. ${ }^{4}$ The Connecticut court has jurisdiction to garnish the debt from the Garnishee Company to Sanders. So far, so good; but suppose that later Sanders sues the Garnishee Company in some other state, S-I, to recover on the debt that has been garnished in the Connecticut suit brought by Armour Fertilizer Works. Has the Garnishee Company any defense by virtue of the Connecticut judgment? That judgment against the Garnishee Company is, by virtue of the full faith and credit clause of the federal Constitution, a bar to the prosecution of Sanders' later action, ${ }^{5}$ save in some exceptional circumstances such as are mentioned in the next paragraph. True, if an appeal from the Connecticut judgment is pending, the later action in the other state, S-r, is, perhaps, only to be continued, or the enforcement of a judgment for Sanders in S-I suspended, until final determination of the Connecticut appeal. ${ }^{6}$ The ultimate aim has been to save the Garnishee Company, the garnishee, from double liability-from liability to Sanders, the principal debtor, after the

3 Chicago, Rock Island \& Pacific Ry. Co. v. Sturm, I 74 U.S. 710 (I899), approved in King v. Cross, 175 U.S. 396, 399 (r899) and Rothschild v. Knight, I84 U.S. 334, 34I (1902).

${ }_{4}$ Chicago, Rock Island \& Pacific Ry. Co. v. Sturm, r74 U.S. 7ro (I89g). $\quad{ }^{5}$ Ibid.

${ }^{6}$ See Chicago, Rock Island \& Pacific Ry. Co. v. Sturm, r74 U.S. 7Io, 7 I3 (I899). 
Connecticut judgment in garnishment-fully as much as to enable Armour Fertilizer Works, the principal or garnishee creditor, to realize upon an asset of Sanders, viz., his claim against the Garnishee Company. ${ }^{7}$

Sanders, the principal debtor, has received less consideration. The Connecticut court could not, indeed, under the circumstances just supposed give a valid judgment in personam against him. ${ }^{8}$ The requisite jurisdiction in personam over him would be lacking.9 Yet a judgment in Connecticut against the Garnishee Company, Sanders' debtor, in favor of Sanders' creditor, it has been seen, may bar any subsequent attempt by Sanders to recover upon his claim against the Garnishee Company. His interests have been held sufficiently protected if he received such notice of the pendency of the garnishment action in Connecticut as would enable him to put in a defense to the claim of Armour Fertilizer Works or if, possibly, the Garnishee Company as garnishee pleaded any exemption that might be allowed Sanders under the law of the forum or under his domiciliary law. If If he were served only constructively in the Connecticut garnishment suit, as has been assumed, and if the Garnishee Company as garnishee did not give him the requisite notice of the pendency thereof, the Connecticut judgment against the garnishee would not bar Sanders' later suit in S-I against the Garnishee Company, ${ }^{\text {II }}$ especially if there had been collusion between Armour Fertilizer Works (the principal creditor) and the garnishee. ${ }^{\text {.2 }}$

Jurisdiction to garnish a simple contract debt, then, seems coterminous with jurisdiction to render a judgment in personam against the garnishee debtor. ${ }^{\mathrm{x}}$ If the garnishee debtor is a corporation, such jurisdiction cer-

7 Harris v. Balk, I98 U.S. 215, 226 (I905).

${ }^{8}$ See statements in Planters' Chemical \& Oil Co. v. Wallar, 160 Ala. $217,224,49$ So. 89, 91 (I909); Veeder Mfg. Co. v. Marshall-Sanders Co., 79 Conn. I5, I7, 63 Atl. 64I, 642 (I906); Templeton v. Van Dyke, I69 Minn. I88, Igr, 210 N.W. 874, 875 (I926); Kemper-Thomas Paper Co. v. Shyer, I08 Tenn. 444, 67 S.W. 856 (I902).

9 Pennoyer v. Neff, 95 U.S. 714, 747 (1878).

Io See Chicago, Rock Island \& Pacific Ry. Co. v. Sturm, I74 U.S. 7Io, 7 I8 (I899). See also statements in Harris v. Balk, I98 U.S. 215, 227-228 (I905) and In re Beals, II6 Fed. 530, 532 (D.C. Ind. I902); and $c f$. Baltimore \& Ohio R. R. v. Hostetter, 240 U.S. 620 (I9I6).

${ }^{11}$ Cf. Harris v. Balk, I98 U.S. $25_{5}$ (I905), and Baltimore \& Ohio R. R. v. Hostetter, 240 U.S. 620 (IgI6).

${ }^{12}$ For a case where there may have been collusion see Stewart v. Northern Assurance Co., 45 W. Va. 734, 32 S.E. 218 (I898).

${ }^{23}$ Harris v. Balk, I98 U.S. $2 x_{5}$ (1905). See also statements in H. Williamson, Ltd. v. Phinney-Walker Co., 247 Mich. 645, 647, 226 N.W. 672 (I929); Templeton v. Van Dyke, I69 Minn. 188, I9I-93, 210 N.W. 874, 875-76 (I926), which explains and discusses earlier Minnesota cases; Bingenheimer Mercantile Co. v. Weber, 49 N.D. 3I2, 3I7, I9x N.W. 620, 62I (I922). 
tainly exists in the state of incorporation. In the initial United States Supreme Court case on the problem ${ }^{\text {r4 }}$ garnishment outside the state of incorporation of a garnishee debtor was not considered. In Harris $v$. $B a l k,{ }^{15}$ however, a judgment was rendered against a natural person as garnishee in Maryland, in which he was served while only temporarily present. The principal debtor was served only constructively. This judgment against the garnishee was held to be a bar to a later action against. him in his domicil, North Carolina, which the debtor-creditor instituted for the recovery of the debt that had been the subject of the garnishment in Maryland. "Power over the person of the garnishee confers jurisdiction on the courts of the state where the writ issues." "I6 To dispose of the contention that it was necessary that jurisdiction be had of the person of the debtor-creditor as a prerequisite to jurisdiction to garnish, the court declared that the garnishee creditor sued as agent for the debtorcreditor. ${ }^{17}$ The fictitious character of such an agency has been sufficiently pointed out elsewhere. ${ }^{18}$ In the hypothetical case under consideration, therefore, Armour Fertilizer Works would not be limited to Connecticut if it wished to sue in garnishment. The Garnishee Company is assumed to be lawfully engaged in business in Tllinois and subject to suit there. Armour Fertilizer Works could bring a garnishment action in that state. ${ }^{19}$ If Sanders were served only constructively, but personal service were had on the Garnishee Company, the same results could follow as we have seen might result from the Connecticut garnishment suit.

Under the decision in Chicago, Rock Island \& Pacific Ry. Co. v. Sturm, ${ }^{20}$ as extended in Harris v. Balk, reasonable assurance of freedom from double liability was granted a garnishee who had paid a judgment recovered against it on personal service in any of the United States. ${ }^{2 x}$ Creditors had assurance of considerable facility in realizing upon debts owed to their

${ }_{4}$ Chicago, Rock Island \& Pacific Ry. Co. v. Sturm, I74 U.S. 7 10 (I899).

xs 198 U.S. $2 x_{5}$ (Ig05).

${ }^{16} \mathrm{Id}$. at 222.

${ }_{77} I d$. at 226 .

${ }^{28}$ See Goodrich, Conflict of Laws I29-30 (I927); Beale, The Exercise of Jurisdiction in Rem to Compel Payment of a Debt, 27 Harv. L. Rev. Io7, I2x-22 (I9I3).

${ }_{19}$ This appears from Sanders v. Armour Fertilizer Works, 292 U.S. I90 (1934).

${ }^{30}$ I 74 U.S. 7 ro (189g).

${ }^{2 x}$ In cases where the probability was that a gamishee might later be held liable abroad to the principal debtor, who had been served only constructively in the garnishment suit, courts have refused to enter judgment against the garnishee: Weitzel v. Weitzel, 27 Ariz. II 7,230 Pac. 1106 (I924); and $f f$. Parker, Peebles \& Knox v. National Fire Ins. Co., III Conn. 383, I50 Atl. $3^{1} 3$ (I930) and Universal Adjustment Corp. v. Midland Bank, 28r Mass. 303, I84 N.E. 152 (I933). See also dictum in Kidder v. Packard, I3 Mass. 80, 82 (I8r6). If a garnishee is sued abroad by the principal debtor while the garnishment suit is pending, the duty rests on the garnishee to bring the pendency of the garnishment suit to the attention of the foreign 
debtors by third persons, especially when the garnishee debtor was a corporation subject to suit in more than one state.22 Some critics did fear that a fraudulent garnishment action would often be brought in a state far removed from the domicil of the principal debtor. ${ }^{23}$ Others felt that Harris v. Balk furnished adequate protection against such a danger by its warning that ordinarily "the failure on the part of the garnishee to give proper notice to his creditor of the levying of the attachment would be such a neglect of duty on the part of the garnishee . . . . as would prevent his availing himself of the judgment in the attachment suit as a bar to the suit of his creditor against himself. . . . ${ }^{\prime 24}$ From the reported cases it may well be that employees of interstate railroads have good reason to complain of the two United States Supreme Court cases just cited. An employee of an interstate railroad finds that his wages have been garnished in a state in which his employer (the railroad) is subject to suit, but in which he is neither domiciled nor employed and in which the wages have not been earned and are not payable. ${ }^{25}$ The amount at stake in such a suit is often so small that it is not unreasonable to assume that the expense of defending against the claim of his alleged creditor forces the railroad employee to submit to the garnishment of his wages in a foreign state at the suit of one whose claim is of dubious legality. This hardship may, perhaps, be removed by statutes, such as those which make it an offense for a creditor, with intent to evade the state exemption laws, to send a claim out of the state for collection by garnishment when all the parties (the principal creditor, the principal debtor and the garnishee) are within the jurisdiction of the courts of the state. ${ }^{26}$

court: Bayer v. Lovelace, 204 Mass. 327,90 N.E. 538 (rgro). If the garnishee does not do so, a judgment by such foreign court against him is no bar to judgment against him in the garnishment suit.

22 E.g., Louisville \& Nashville R. R. Co. v. Deer, 20o U.S. I76 (I9o6).

${ }^{23}$ Beale, The Exercise of Jurisdiction in Rem to Compel Payment of a Debt, 27 Harv. L. Rev. 107, 12I-22 (r913).

${ }^{24}$ Carpenter, Jurisdiction over Debts for the Purpose of Administration, Garnishment, and Taxation, 31 Harv. L. Rev. 905, 915-18 (r9r8).

${ }^{25}$ See, for example, Pittsburg, C.C. \& St.L. Ry. Co. v. Bartels, ro8 Ky. 216, 56 S.W. r52 (1900); Williams v. St. Louis \& S.W. Ry. Co., rog La. 90, 33 So. 94 (I902); Missouri, K. \& T. Ry. Co. v. Swartz, 53 Tex. Civ. App. 389, Ix5 S.W. 275 (rgog); Baltimore \& Ohio R. Co. v. Allen, 58 W. Va. $388,5_{2}$ S.E. 465 (1905).

${ }^{26}$ E.g., Ga. Code r933, \$§ 46-209, 2I0, 2Ir, and 46-990r; Ill. Rev. Stat. I935, c. 52, Tf 20-2I; Burns Ind. Stat. I933, § Io-4904; Iowa Code I935, § II770; N.C. Code I935, §§ 656872 (forbidding transmission of contract claims against a "resident wage-earner or other salaried employee of any railway corporation or other corporation, firm, or individual engaged in inter-state business"); Wis. Stat. 1935 , § 343.407. 
Harris v. Balk was concerned with the duty of a court to give full faith and credit to the judgment of a court of a sister state against a garnishee debtor. However, it has persuaded many state courts to adopt or to reaffirm the doctrine that, whenever state statutes so permit, personal jurisdiction over the garnishee debtor suffices to give jurisdiction in garnishment of a simple contract debt. ${ }^{27}$ Non-residence of the debtor-creditor may be regarded as immaterial. ${ }^{28}$ So also may the place where the garnished debt has been contracted. ${ }^{29}$ And the place where it is payable. ${ }^{30}$

With such reasonable assurance of freedom from double liability a garnishee debtor was supposed to occupy a position of neutrality as an indifferent stakeholder. ${ }^{3 x}$ It was no concern of his who ultimately collected the debt he owed-the garnishee creditor or the principal debtor. Payment of a judgment in favor of the principal creditor discharged the garnishee from liability to the debtor-creditor..$^{32}$

Suppose that several plaintiffs seek in separate suits in different states to garnish a corporation that is subject to suit in each state for a debt due one who is alleged to be indebted to each of these plaintiffs. For example, in states $\mathrm{S}-\mathrm{I}, \mathrm{S}-2$ and $\mathrm{S}-3$, respectively, A, B and C seek to recover debts alleged to be due them from $D$. In their respective actions against $\mathrm{D}$ each of the three plaintiffs (A, B and C) garnishes the Garnishee Company, a corporation that is lawfully transacting business in states S-I, S-2 and S-3, and subject to suit in each. Suppose that A's action in state S-I was the first to be instituted, and that he had served garnish-

${ }^{27}$ See, for example, Person v. Williams-Echols Dry Goods Co., II3 Ark. 467, I69 S.W. 223 (Igr4); H. Williamson, Ltd. v. Phinney-Walker Co., 247 Mich. 645, 226 N.W. 672 (I929); Southern Pacific R. Co. v. A. J. Lyon \& Co., 99 Miss. $x 86,54$ So. 728 (r91I); Shiatte v. Singer Mfg. Co., 8r N.H. 294, r25 Atl. 429 (r924); Bingenheimer Mercantile Co. v. Weber, 49 N.D. 312, I9r N.W. 620 (I922); Bristol v. Brent, 38 Utah 58, r тo Pac. 356 (Igro), but $o f$. Mathison v. Richard, 48 Utah 226, 158 Pac. 787 (rgI6).

${ }_{28}$ "The garnishment of a debt due a nonresident by a resident debtor is recognized by our statutes and by repeated decisions as being a suit in rem against the attached debt, the effect of which is to subject it to the payment of the amount due the plaintiff. This right to subject the obligation of nonresident does not, under the holdings of our courts, infringe upon the sovereignty of the state of the nonresident's domicile." Gerlach Mercantile Co. v. HughesBozarth-Anderson Co., I89 S.W. 784, 788 (Tex. Civ. App. 1916).

${ }^{29}$ Person v. Williams-Echols Dry Goods Co., Ir3 Ark. 467, I69 S.W. 223; H. Williamson, Ltd. v. Phinney-Walker Co., 247 Mich. 645, 226 N.W. 672 (I929).

${ }^{30}$ Harvey v. Thompson, I28 Ga. I47, 57 S.E. I04 (I907); Morrison v. Illinois Central R. Co., IOI Neb. 49, I6I N.W. I032 (I9I7).

${ }_{32}$ "The relation of the garnishee to the parties is well defined by the authorities. He stands as a mere stakeholder, and must not voluntarily do anything to the prejudice of the parties. He must let the law take its course, except he may protect himself from unauthorized acts and proceedings." Brondum v. Rosenblum, I5I Miss. 91, 98, II7 So. 363,364 (I928).

${ }^{32}$ Garnishment of judgments is not here considered. 
ment process on the Garnishee Company before the institution of B's action in S-2 or C's in S-3. Would the pendency of A's action in S-I bar B's later garnishment of the Garnishee Company in S-2? There is at least one decision that mere pendency of garnishment in one state does not bar garnishment of the same debt in another state if the garnishee is a corporation subject to suit in each state. ${ }^{33}$ That decision has met with no disapproval by the United States Supreme Court. ${ }^{34}$ A judgment recovered in any one of the three states-S-I, S-2 or S-3, for example-is entitled to full faith and recognition in each of the others, that is, a judgment against the Garnishee Company as garnishee in one of these states bars another judgment against it as garnishee of the same debt in other states, assuming, of course, the absence of any collusion between the Garnishee Company and the judgment creditor and that requisite notice was given the principal debtor. That plaintiff will prevail who first secures a judgment. Here again it seems that the garnishee corporation occupies the position of stakeholder. In any suit in which the principal debtor is not personally served, the Garnishee Company is under a duty to notify the principal debtor of the pendency of the suit, to plead the pendency of garnishment suits on the same debt in other states, and, perhaps, to plead any exemptions allowed the principal debtor under his domiciliary law. Its duties extend no further. It may rely on the first judgment against it as garnishee to bar the rendition of judgments in other states on the same debt.

\section{II}

The recent case of Sanders v. Armour Fertilizer Works ${ }^{35}$ shows that in certain cases the Federal Interpleader Act ${ }^{36}$ makes possible a change in the position of a corporate garnishee. It is submitted that in certain cases a corporation that is a garnishee debtor may now exercise some control as to which of several competing garnishing creditors shall prevail. Its position is no longer that of a mere stakeholder. Moreover, in those cases, winning a race to priority of judgment may no longer be a matter of concern to the garnishing creditors themselves. For the sake of clarity Sanders v. Armour Fertilizer Works will be stated in detail.

Armour Fertilizer Works, an Tllinois corporation, brought an action in Tllinois against Sanders, a citizen and resident of Texas, on notes payable in Texas. These notes purported to waive all exemption and homestead rights. Sanders was served by publication only. However, the plaintiff

33 Lancashire Ins. Co. v. Corbetts, I65 Ill. 592, 46 N.E. 63 I (I897).

${ }^{34}$ See Sanders v. Armour Fertilizer Works, 292 U.S. Igo (I934).

35292 U.S. Igo (I934).

${ }^{36} 49$ Stat. Iog6 (I936); 28 U.S.C.A. § 4 I (26) (I926) (as amended). 
garnished in Mlinois in foreign attachment two Connecticut insurance companies on their indebtedness to Sanders on policies insuring Texas premises against fire. The insurers did business in both Tllinois and Texas. In their answers they admitted their respective liabilities, but set up that Sanders claimed the proceeds as exempt from garnishment under the Texas homestead laws. Before trial of the issues raised by their answers the garnishees filed bills under the Federal Interpleader Act ${ }^{37}$ in the United States District Court for the Eastern District of Texas, in which Sanders was domiciled, naming him and Armour Fertilizer Works as adverse claimants. These two interpleader suits were consolidated. The insurance companies paid the amounts due on the policies into court which issued a preliminary injunction restraining further proceedings against the insurance companies in the Illinois action brought by Armour Fertilizer Works. By this time judgment had been entered against Sanders in that action, the attachment in garnishment sustained and the issue of execution ordered. The United States District Court on motion dismissed the bills in interpleader, holding that the claims of Sanders and Armour Fertilizer Works were not adverse. ${ }^{38}$ The Circuit Court of Appeals reversed the decree. ${ }^{39}$ It found the claims of Armour Fertilizer Works and Sanders to be adverse so as to entitle the insurance companies to the benefits of the Federal Interpleader Act. Trial on the merits in the District Court then resulted in a decree for Sanders, but on appeal this was reversed on the ground that the District Court had not given full faith and credit to the Mlinois judicial proceedings..$^{4}$ On certiorari the United States Supreme Court upheld the Circuit Court of Appeals and adjudged Armour Fertilizer Works to have the superior "equity" in the proceeds of the insurance policies. The Chief Justice and Justices Brandeis, Cardozo and Stone dissented.

Two cases from the Supreme Court of Illinois were cited by both the majority and minority as authority for certain of their respective statements. Speaking for the majority, Mr. Justice McReynolds said:

The Illinois rule is that garnishment imposes an inchoate lien subject to defeat by certain subsequent events, none of which are present here. Also, that final judgment in Illinois against the garnishee prior to one in another jurisdiction is conclusive of the rights of the parties. Lancashire Ins. Co. v. Corbetls, I65 Ill. 592; 46 N.E. 63I; Becker v. Illinois Central R. Co., 250 Ill. $40 ; 95$ N.E. $4^{2.4^{x}}$

37 The bills were filed under the Act of May 8, Ig26, 44 Stat. 4 I6 (I926); 28 U.S.C.A. $\S 4 \mathrm{I}$ (26) (Ig26).

${ }^{38}$ Nat'l Fire Ins. Co. v. Sanders, 33 F. (2d) I 57 (D.C. Tex. I929).

${ }^{39}$ Nat'l Fire Ins. Co. v. Sanders, 38 F. (2d) 212 (C.C.A. 5th 1930).

${ }^{40}$ Armour Fertilizer Works v. Sanders, 63 F. (2d) 902 (C.C.A. 5th I933).

4I Sanders v. Armour Fertilizer Works, 292 U.S. I90, 203 (I934). 
According to Mr. Justice Cardozo, speaking for the minority:

The Illinois plaintiff, though the first to have recourse to garnishment, will be postponed to the other plaintiff who is first with execution. Lancashire Ins. Co. v. Corbetts, r65 III. $59^{2} ; 46$ N.E. 63 r. Indeed the primary creditor, i.e., the debtor of the attaching plaintiff, may bring suit against the garnishee in another jurisdiction, and collect the indebtedness if he wins the race to judgment. Becker v. Illinois Central R. Co., 250 IIl. $40 ; 95$ N.E. $4^{2.4^{2}}$

The two statements are not inconsistent. Both agree that in Illinois a plaintiff by the mere service of attachment in garnishment does not secure an indefeasible right to have any judgment he may recover against the principal debtor satisfied out of the proceeds of the garnished debt. Both make priority in time of a judgment against the garnished debtor in Mllinois over a judgment against him elsewhere on the garnished indebtedness a material, even a conclusive, factor. What is more, neither the majority nor the minority group point to any inconsistency in the act of the other in citing these two Illinois cases. Do these two cases, then, accord with the decision of the majority and with the decision of the minority?

In Lancashire Ins. Co. v. Corbetts ${ }^{43}$ a British insurance company, lawfully transacting business in Illinois and Wisconsin, owed a debt to Corbetts, a resident of Wisconsin. A creditor of Corbetts served the insurance company with an attachment in garnishment of that debt in a suit in Tllinois. Corbetts received only constructive service. Thereafter another creditor of his sued in Wisconsin and garnished the same indebtedness. In the Wisconsin action the insurance company pleaded the pendency of the Illinois garnishment suit. The Wisconsin court, however, reasoned that Tllinois had lacked jurisdiction to garnish this debt due from a British corporation to a Wisconsin resident. Accordingly, the Wisconsin court held the plea no defense and gave judgment against the garnishee, which it paid under compulsion. The garnishee then pleaded the Wisconsin judgment and such compulsory payment in bar of the Mlinois garnishment. The trial and appellate courts of Mlinois held against the insurance company, but on appeal the supreme court of the state decided in its favor. That court was of the opinion that while the Wisconsin court had followed unsound reasoning in giving judgment against the insurance company as garnishee, both Tllinois and Wisconsin had jurisdiction in garnishment because the company could have been sued by its creditor in either one of those states. Jurisdiction was concurrent. Neither state had exclusive jurisdiction. Therefore, the judgment first rendered was

${ }_{42}$ Id. at 207 . ${ }_{43}$ I65 IIl. 592, 46 N.E. 63 I (I897). 
valid and enforceable against the garnishee. A second payment of the debt was not to be compelled. The garnishee was not to stand in any worse position because of the garnishment. It was not to incur any greater liability.

Lancashire Ins. Co. v. Corbetts, read in the light of Harris v. Balk, clearly gives priority to that one of several garnishee creditors who is the first to secure judgment against the garnishee debtor. As between several plaintiffs who in different states are garnishing the same corporate debtor of their common debtor, preference rests with him who first secures judgment. Such seems to have been the interpretation of both the majority and minority in the United States Supreme Court. Nowhere in the opinions of that court in Sanders v. Armour Fertilizer Works is there any criticism of the premises of the Mllinois Supreme Court in Lancashire Ins. Co. v. Corbetts that both Illinois and Wisconsin had jurisdiction in garnishment.

In Becker v. Illinois Central R. R. Co., ${ }^{44}$ also cited by both majority and minority of the United States Supreme Court in Sanders v. Armour Fertilizer Works, Miller of Missouri was the assignee of an Mlinois creditor of an Tllinois employee of the Tllinois Central Railroad. Miller, as such assignee, brought an action in Missouri against the railroad employee, serving him only by publication. The railroad was served as garnishee on its indebtedness to the employee for wages earned in Tllinois. In its answer the railroad company admitted the debt, but pleaded that the same was exempt from garnishment under the statute of Illinois and that under the law of Missouri the writ of attachment and garnishment notice were null and void. It moved for a dismissal of the action as against it. Thereafter the employee recovered judgment for the wages in question before a justice of the peace in Illinois, from which the railroad appealed to the circuit court. Pending that appeal a judgment was entered in the proceedings in garnishment in Missouri against the railroad as garnishee and paid. The Illinois circuit court held that the Missouri judgment and the payment thereof were not a good defense to the employee's action against the railroad. It gave judgment for the employee. On appeal the appellate court affirmed this judgment. Upon a certificate of importance and appeal the supreme court of the state also affirmed the judgment, saying:

When judgment was rendered against the appellant in this state for wages exempt from garnishment, payment of the judgment would have been a good defense to the further prosecution of the suit in Missouri. The appeal to the circuit court was a volun-

44250 IIl. 40,95 N.E. 42 (IgII). 
tary act of the appellant, with the effect of letting in a foreign judgment which had been rendered against the appellant in Missouri and paid before the trial in the circuit court. Such a voluntary act in a case where the appellant had no defense to the claim could not, without injustice, be permitted to affect the rights of the appellee. By the service of the garnishee summons in Missouri Miller acquired a contingent or inchoate lien upon the debt and appellant could not thereafter make a voluntary payment to the appellee, but the right which Miller acquired was dependent upon subsequently obtaining judgment, and that was not accomplished until a judgment had been recovered in this State, where the debt was free from any right or claim that he had. 45

This case is not concerned with the rights of competing garnishee creditors, as was Lancashire Ins. Co. v. Corbetts. The clash is one between a garnishee creditor and the debtor-creditor. As between those two, however, the case, read in the light of Harris v. Balk, gives priority to that party who is the first to secure judgment against the corporate garnishee debtor. As in Lancashire Ins. Co. v. Corbetts, priority in securing judgment is the material factor. And such seems to have been the interpretation of the case by both the majority and minority of the United States Supreme Court in Sanders v. Armour Fertilizer Works.

Obviously the United States Supreme Court does not purport to hold these two Illinois cases unsound. It does not find that the Mllinois court violated or disregarded any provision of the United States Constitution. Has Sanders v. Armour Fertilizer Works in any way modified the working of these Illinois cases? Consideration will now be given that problem.

III

CASE I

Assume the following facts:

The Armour Fertilizer Works commences an action in Tllinois against Sanders. He is served only constructively, but an attachment in garnishment is served on the Garnishee Company, a Connecticut insurance company. The garnishee in its answer admits its indebtedness to Sanders, but sets up that the proceeds of his claim against it would be exempt from garnishment under the Texas homestead laws. A default judgment is entered against Sanders..$^{4^{6}}$ Meanwhile in state S-I another action has been brought against Sanders by another creditor of his, whom we will call $\mathrm{X}$. - $45 I d$. at 45,95 N.E. at 43 .

${ }_{4}^{6}$ Such a judgment, of course, would impose no personal obligation on Sanders for lack of the requisite jurisdiction in personam over him. See statements in Planters' Chemical \& Oil Co. v. Wallar, r6o Ala. 217, 224, 49 So. 89, 9r (rgog); Veeder Mfg. Co. v. Marshall-Sanders Co., 79 Conn. 15, 17, 63 Atl. 641, 642 (rgo6); Templeton v. Van Dyke, 169 Minn. 188, r9x, 210 N.W. 874, 875 (r926); and Kemper-Thomas Paper Co. v. Shyer, I08 Tenn. 444, 67 S.W. 856 (1902), all cited in note 8 supra, and Pennoyer v. Neff, 95 U.S. 7 74, 727 ( 1878 ), cited in note 9 supra. 
In that action Sanders is personally served. The Garnishee Company is lawfully transacting business in state S-I as well as in Tllinois and in X's action in state S-I it is served with an attachment in garnishment of the same debt on which it has already been garnished in Jllinois. Again, as in the Illinois action, the garnishee in its answer admits its indebtedness to Sanders and sets up the same claim of exemption. It also pleads the pendency of the garnishment proceeding in Illinois. Before any final judgment is entered against the Garnishee Company in either Illinois or state S- $I$, it files a bill under the Federal Interpleader Act in the United States District Court in the district in Texas in which Sanders is domiciled. He, $\mathrm{X}$ and Armour Fertilizer Works are made parties. The Garnishee Company pays the amount at stake into court and is discharged. Injunctions issue restraining further prosecution of the actions in Tllinois and state S-r. What decision should the federal court render?

In this hypothetical case, as in the reported case of Sanders v. Armour Fertilizer Works, the United States District Court in Texas will not be primarily concerned with the rights of a garnishee. The Garnishee Company has paid its debt into court and obtained a complete discharge. Only Sanders, $\mathrm{X}$ and the Armour Fertilizer Works are interested. Presumably, also, as in the reported case, Armour Fertilizer Works "asks nothing under any Texas law." 47 It has been brought into the United States District Court against its will and held there against its protest. So also has X. $\mathrm{He}$, too, asks nothing under any Texas law. Armour Fertilizer Works claims the proceeds of the policy to the exclusion of the other interpleaded parties by virtue of its Illinois attachment in garnishment. $\mathrm{X}$ makes a similar claim by virtue of his attachment in state S-I. Sanders, while not disputing his obligation to either of these creditors of his, claims the proceeds by virtue of the Texas homestead exemption statutes. Both X and the Armour Fertilizer Works admit that the Garnishee Company is primarily indebted to Sanders and each seeks to recover because of Sanders' indebtedness to it. Each of the three-Armour Fertilizer Works, Sanders and X-claims the proceeds of the policy to the exclusion of the other two. They would seem to be adverse claimants within the scope of the Federal Interpleader Act. ${ }^{8}$ In determining who is entitled to the proceeds of the debt due from the Garnishee Company to Sanders the court will "weigh the right or title of each claimant under the law of the state in which it arose, and determine which according to equity is the better." 49

47292 U.S. 190, 200.

$4^{8}$ Id. at 199.

49 Id. at 200, where the court quotes from the opinion in the Circuit Court of Appeals in 63 F. (2d) 902 , 906 (C.C.A. 5th I933). 
What, then, as to the right or title of Armour Fertilizer Works in this hypothetical case? What had it secured under the law of nlinois? It is in the answer to this question that the majority and minority of the Supreme Court differed in the reported case of Sanders v. Armour Fertilizer Works. The majority find that Armour Fertilizer Works, by virtue of the service of the attachment in garnishment, acquired a lien on the garnished debt subject to defeat if certain events subsequently happened. ${ }^{\text {so }}$ Lancashire Ins. Co. v. Corbetts shows that one of such subsequent events would have been the recovery of a judgment in state S-I against the garnishee insurance companies before any judgments were recovered against them in Illinois. In other words, as has already been pointed out, Armour Fertilizer Works in the hypothetical case gets an indefeasible right under the law of Tllinois to have the proceeds of the garnished debt applied in satisfaction of its claim against Sanders only if and when it is the first to secure a judgment, based on personal service, against the garnished corporation. How can it secure such priority when it has been enjoined from further prosecution of its Illinois action? How can it prevail in the interpleader suit? Only if the court in that suit deems it inequitable to hold that because the last step in the Ilinois action, i.e., the rendering of a judgment against the garnishee, was not taken, either Sanders or $\mathrm{X}$ had in some way become entitled to priority.

In the actual case of Sanders v. Armour Fertilizer Works the Supreme Court of the United States held that the injunction against further prosecution of the Illinois action could not equitably operate so as to deprive Armour Fertilizer Works of the "paramount right or superior equity to the proceeds of the policies" given it by the proceedings in Illinois..$^{5 x}$ The court admittedly was not concerned with a state of facts in which some other creditor of Sanders was also interested in the garnished debts. ${ }^{52}$ If no such other creditor appears on the scene before the decree in interpleader is rendered, it may be that full faith and credit require that the injunction against further prosecution of the Illinois action should not deprive Armour Fertilizer Works of any "inchoate lien," "paramount right" or "superior equity" it had already gained.

However, in the hypothetical case, $X$, the state S-I creditor of Sanders, may be able to show that under the law of state S-I the institution of his action against Sanders and the service upon the Garnishee Company of his attachment in garnishment would have entitled him to have his judgment against Sanders satisfied out of the proceeds of the garnished debt in the absence of a prior judgment in some other state rendered, after

so Id. at 203 .

sr Id. at 204 .

$52 I d$. at 205 . 
personal service, against the Garnishee Company-either a judgment against it in garnishment in favor of some other creditor of Sanders ${ }^{53}$ or a judgment against it in favor of Sanders as plaintiff. ${ }^{4}$ Under the law of state S-I, then, X would have a "right" or "equity" not "paramount" or "superior," perhaps, to that which Armour Fertilizer Works has under the laws of Illinois, but certainly not inferior. Whom will the United States District Court in Texas prefer if it seeks to weigh the right or title of each under the law of the state in which it arose and to determine which "right" or "equity" is the better? X has been enjoined from further prosecution of the action in state S-I. He cannot take the "last step" in state S-r. Would it not be inequitable, according to the reasoning of the United States Supreme Court, to hold that because X had not taken such "last step" either Armour Fertilizer Works or Sanders had in some way become entitled to priority-i.e., to the proceeds of the garnished debt?

Would it be equitable for the United States District Court in Texas to award the fund to Armour Fertilizer Works? True, that claimant has been enjoined from taking the last step in Tlinois-securing a judgment, based on personal service, against the garnishee. It does not follow, however, that it has obtained an indefeasible right to the fund, superior to the claims of other claimants, $\mathrm{X}$, for example. To make this point clear, suppose that no interpleader had been filed in the hypothetical case. While the suits were pending in Tllinois and state S-I, counsel for Armour Fertilizer Works, if learned in the law of Illinois and in the decisions of the United States Supreme Court, would advise the client that it would secure an indefeasible right to have the proceeds of the garnished debt applied in payment of its claim against Sanders only if it secured an Illinois judgment against the garnishee before any judgment were entered against the garnishee in state S-I. Counsel for X, if learned in the law of state S- $x$ and in the decisions of the United States Supreme Court, would advise $\mathrm{X}$ that he would secure an indefeasible right to have the proceeds of the garnished debt applied in payment of his claim against Sanders only if he- $X$ - secured a judgment in state $S-I$ against the garnishee before any judgment were entered against the garnishee in Illinois. With the filing of the interpleader suit in the hypothetical case it becomes impossible in practice for a judgment to be recovered in Illinois before a judgment is recovered in state S-I and equally impossible for a judgment to be recovered in state S-I before a judgment is recovered in Mllinois. Armour Fertilizer Works and $X$ have been enjoined from prosecuting their re-

53 See Lancashire Ins. Co. v. Corbetts, 165 Ill. 592, 46 N.E. 63 I (1897).

54 See Becker v. Tllinois Central R.R. Co., 250 Ill. 40, 95 N.E. 42 (IgII). 
spective garnishment suits in Tllinois and state S-I. Priority of judgment in one or the other of those two states cannot be a fact for the court in the interpleader suit to consider. It is a fact that does not, and in practice will not, exist. It is absurd to suppose that either Armour Fertilizer Works or $\mathrm{X}$ would disobey the injunctions issued by the court in the interpleader suit. Yet it is priority of judgment that the Illinois court in Lancashire Ins. Co. v. Corbetts considers the decisive factor. It seems, therefore, that so far Armour Fertilizer Works in the hypothetical case has not proven that under Illinois law it has obtained a "right" or "equity" which the court in the interpleader case should regard as "paramount" to any "right" or "equity" that $X$ claims under the law of state S-I, unless priority in service of garnishment in Tllinois over service of garnishment in state S-I is the decisive factor. If such priority is to be regarded as the decisive factor and Armour Fertilizer Works is to prevail, then query whether the court in the interpleader suit is determining the "right" or "title" of Armour Fertilizer Works under the law of Illinois. It is respectfully submitted that it is not.

On the other hand the court could not award the fund to X consistently with Chicago, Rock Island \& Pacific Ry. Co. v. Sturm and Harris v. Balk. To make this clear, suppose that no interpleader had been filed in the hypothetical case. Had Illinois been the first to render judgment against the Garnishee Company, there would have been no doubt as to the obligation of the court in state S-I to extend full faith and credit to the Mllinois judgment. Yet the court in state S-I might refuse to regard the mere pendency of the Tllinois garnishment suit as a bar to the prosecution of the suit in state S-I to final judgment against the Garnishee Company. The Wisconsin court did so refuse in the Lancashire Ins. Co. v. Corbetts situation. No criticism of such refusal is to be found in the Supreme Court of the United States. ${ }^{55}$ If the Garnishee Company is a corporation on which personal service can be had in both Illinois and state S-I, there seems to be no constitutional reason why pendency of the Mlinois garnishment suit should bar the later garnishment suit in state S-I. Now return to the interpleader suit in Texas in the hypothetical case. Surely the

ss In speaking of garnishment in Illinois Mr. Justice Cardozo says: "The writ has no effect upon involuntary payments before the stage of judgment. Some other attaching creditor, suing the same defendant, may garnish the same debt in another jurisdiction. The Illinois plaintiff, though the first to have recourse to garnishment, will be postponed to the other plaintiff who is first with execution. Lancashire Ins. Co. v. Corbetts, I65 Ill. 592, 46 N.E. 63 I."' Sanders v. Armour Fertilizer Works, 292 U.S. I90, 207 (I933).

Mr. Justice McReynolds says that the Illinois rule is that "final judgment in Illinois against the garnishee prior to one in another jurisdiction is conclusive of the rights of the parties. Lancashire Ins. Co. v. Corbetts, 165 III. 592, 46 N.E. 63I." Id. at 203: 
court would not prefer $\mathrm{X}$ on the theory that it should give full faith and credit to the garnishment proceedings in state S-I to the exclusion of those in Illinois. To do so would be to deny that a state in which a garnishee is personally served (Illinois) has jurisdiction to render a judgment against the garnishee entitled to external recognition under the federal constitution.

It is hard to believe that the court would dismiss the interpleader suit and remit the respective plaintiffs in Illinois and state S-r to a race for priority of judgment, with an added probability of a suit by Sanders. The Federal Interpleader Act authorizes the court to adjudicate this multicornered dispute. Hard cases may make bad law, but they do not justify a distorted application of the doctrine of forum non conventiens.

The minority of the United States Supreme Court in Sanders v. Armour Fertilizer Works denied that by service of attachment in garnishment Armour Fertilizer Works acquired under Hlinois law a lien on the garnished debt. ${ }^{56}$ The minority included four judges; the majority, five. Evidently the decision produced a fear in some quarters that in some subsequent case the Court might reverse its stand and give the Illinois garnishment statute the interpretation which the minority in Sanders $v$. Armour Fertilizer Works thought was the proper one. At any rate the Illinois General Assembly recently amended the statute regulating attachments in garnishment by providing that those summoned as garnishees shall thereafter hold any property, effects, choses in action or credits in their possession or power belonging to the defendant which are not exempt, subject to the court's order in such proceeding, and shall not pay to the defendant any indebtedness owed to him subject to such order, and such property .... and debts shall be considered to have been attached and the plaintiff's claim to have become a lien thereon pending such suit.s?

It is not unreasonable to suppose that the persons responsible for the amendment had in mind the statement of Cardozo, J., that

Garnishment and attachment today are statutory remedies. They are what the state creating them declares that they shall be. It is of no moment that Illinois might have made their efficacy greater as long as her legislature and courts have preferred to make them less..$^{8}$

The amendment, seemingly, was designed to remove any doubt as to the effect of attachment in garnishment in Illinois. The Illinois General Assembly sought to remove any possibility that in a future case the Supreme Court of the United States might give the Illinois garnishment statute in the form in which it had been presented to the Court the

${ }^{56} 292$ U.S. $190,206-207$.

57 Ill. L. I935, pp. 2ro, 2I4-I5 (italics added).

58292 U.S. I9O, 208. 
interpretation set forth by the minority in Sanders v. Armour Fertilizer Works. Perhaps it was even hoped that a five-to-four decision would be avoided. Through its legislature Illinois sought to give the greatest possible efficacy to attachment in garnishment. It sought, so to speak, to make clear to Cardozo, J., and his associates in the minority that the will of Illinois was that the Illinois statute regulating attachment in garnishment be given the effect permitted by the majority of the Supreme Court of the United States. However, when one keeps in mind that the Supreme Court of the nation has not overruled Chicago, Rock Island \& Pacific Ry. Co.v. Sturm or Harris v. Balk, or subsequent cases affirming them, it seems that this amendment of the Illinois statute gives little aid to the satisfactory solution of the problem raised by the hypothetical case that has been under consideration.

Discussion of the question whether service of the Tlinois attachment in garnishment created a "lien" is unfortunate and beside the point. "Lien" is merely a word that denotes a group of legal relations. The relations that are said to constitute a "lien" in one case may be quite different from those relations that are said to constitute a "lien" in another. For example, liens may be "legal" or "equitable"-the relations may be cognizable in a court of law or only in a court of equity. The legal relations that give an innkeeper a "lien" on the trunk of a non-paying "guest" obviously will differ from the legal relations that are said to constitute a "lien" on an intangible chose in action. Without doubt both groups in the United States Supreme Court agreed that service of attachment in garnishment in Illinois did alter the legal relations between the garnishee debtor corporations and the principal debtor (Sanders) and that such service also altered the legal relations between the principal creditor (Armour Fertilizer Works) and the garnishee debtor corporations. ${ }^{59}$ It seems useless to speak of the change as giving or as not giving rise to a lien. The reason why jurisdiction to garnish exists in a state with personal jurisdiction of a garnishee debtor is not that service of the garnishment writ creates a "lien" - that it causes a change in the legal relations. That is the point at issue-whether service of such a writ should cause any such change. A state that has physical power over a garnishee debtor has power to attach unpleasant consequences to a failure on the latter's part to obey the writ and any subsequent judgment. That fact probably explains why jurisdiction to garnish was held to be with a state that had personal jurisdiction of the garnishee debtor. ${ }^{00}$

s9 $C f$. statements of majority in 292 U.S. Igo, 203-204 with statements of minority in 292 U.S. I9o, 206-207.

${ }^{60}$ See Chicago, Rock Island \& Pacific Ry. Co. v. Sturm, I74 U.S. 710, 716, ig Sup .Ct. 797, 800 (1899). 


\section{- IV}

The problem presented in that hypothetical case is one of a type that arises in a situation in which two or more states have enacted statutes that in operation may conflict with one another, but none of which are violative of the federal Constitution. We have seen from the prior discussion of certain United States Supreme Court cases that jurisdiction for garnishment exists in any state in which a garnishee debtor may be sued by his creditor-the so-called debtor-creditor. If the garnishee debtor is a corporation doing business in more than one state, each of those states may enact a statute providing for the garnishment of a debt such corporation owes. Each of those statutes is within the legislative competence, under the federal Constitution, of the enacting state. It does not follow, however, that each statute is entitled to full faith and credit in every other state. So to hold would result in a hopeless clash. The duty is cast ultimately on the Supreme Court to decide which state in a particular set of facts makes out the stronger case for extra-state recognition of its statute.

The extension of full faith and credit to statutes has not been considered by the Supreme Court as often as the giving of full faith and credit to foreign judgments. ${ }^{6}$ However, authority is not lacking for the suggestion that in the hypothetical case under consideration the problem is one of selecting a statute for extra-state recognition. The Supreme Court of the United States has undertaken a similar burden in deciding that California was entitled to enforce its own Workmen's Compensation Act in a state of facts in which the California court could properly have given full faith and credit to the Alaska Workmen's Compensation Act. ${ }^{62}$

In that case a contract of employment was executed in California between a corporate employer and a non-resident alien for the latter's employment in Alaska during a salmon-canning season. The contract required the employer to transport the employee to Alaska. At the end of the season it was to return him to San Francisco and there pay him his wages, less advances. The contract stated that the parties had elected to be bound by the Alaska Workmen's Compensation Act and stated that the parties should be subject to and bound by the provisions thereof. The Alaska statute made no distinction between residents and non-residents and gave a remedy in the territorial courts to every employee injured in the course of his employment in Alaska. The California Workmen's Compensation Act was administered by a Commission and, as interpreted by

${ }_{6 x}$ See 45 Yale L. J. 339 (I935).

62 Alaska Packers Ass'n v. Industrial Accident Commission of California, 294 U.S. 532 (I935). 
the state courts, extended to injuries suffered outside of California if the contract of hire was made therein. It further provided that exemption of an employer from statutory liability could not be gained by any contract, rule or regulation. After his return to California the employee (a nonresident alien, as has been stated) applied for and received an award by the California Commission for injuries suffered in the course of his Alaskan employment. On petition for review by the state supreme court the employer attacked the California Workmen's Compensation Act as invalid under due process and more particularly it challenged the statute as denying due process insofar as it denied validity to the agreement that the parties should be bound by the Alaska statute and insofar as it attempted to give a remedy for injuries suffered outside of the state. The employer also pleaded that the application of the California statute resulted in a denial of full faith and credit to the Alaska statute insofar as the latter statute provided for an exclusive remedy in the territory. The award by the California Commission was upheld by the supreme court of the state. ${ }^{63}$

The judgment of the state court was affirmed by the federal Supreme Court, which assumed that in Alaska "the employee, had he chosen to do so, could have claimed the benefits of the Alaska statute, and that if any effect were there given to the California statute, it would be only by comity or by virtue of the full faith and credit clause. ${ }^{63 a}$

Prima facie every state is entitled to enforce in its own courts its own statutes, lawfully enacted. One who challenges that right, because of the force given to a conflicting statute of another state by the full faith and credit clause, assumes the burden of showing, upon some rational basis, that of the conflicting interests involved those of the foreign state are superior to those of the forum..$^{64}$

Equally significant for present purposes is the statement that

The interest of Alaska is not shown to be superior to that of California. No persuasive reason is shown for denying to California the right to enforce its own laws in its own courts, and in the circumstances the full faith and credit clause does not require that the statutes of Alaska be given that effect. ${ }^{65}$

Return to the hypothetical case. Consider the task of the federal court in Texas in the interpleader suit instituted by the Garnishee Company. That court obtains some light as to how to dispose of the contentions of the various parties from the case of Alaska Packers Association v. Industrial Accident Commission, the case just stated. The Texas federal court

${ }_{63}$ I Cal. (2d) 250, 34 P. (2d) 716 (1934).

${ }^{638}$ Alaska Packers Ass'n v. Industrial Accident Commission of California, 294 U.S. 532, 540 (I935).

${ }^{64} \mathrm{Id}$. at $547-48$. 
must make some disposition of the fund paid in by the Garnishee Company. Sanders claims to be entitled to it by virtue of the Texas homestead statutes, $X$ by virtue of the garnishment suit he instituted in state S-I, and Armour Fertilizer Works by virtue of its garnishment suit in Hlinois. It may be assumed that the court disregards the claim of Sanders. The garnishment statutes of both Mlinois and state S-I seem to be constitutional. It would not follow that each was entitled to extra-state recognition. The federal court in Texas must decide which statute, in the light of all the facts, is the statute of the state with the "superior interest." How is this decision to be made? Various factors may be material. Perhaps $\mathrm{X}$ is to be preferred on the ground that in his garnishment suit in state S-I he was able to secure personal service on Sanders, whereas in Illinois Armour Fertilizer Works was not able to secure such service upon the principal debtor. In other words, the statute of state S-I would be the statute of the state with the "superior interest." But suppose that the debt from Sanders to Armour Fertilizer Works was contracted in the course of a business conducted on behalf of Sanders in Tllinois. That fact, along with the priority in service of the Hlinois garnishment over the service of garnishment in state S-I, might well lead the court in the interpleader suit to hold that the Illinois garnishment statute had been enacted by the state with the "superior interest" and to award to Armour Fertilizer Works the fund paid into court by the Garnishee Company. In many cases it may be that priority in filing suit or in serving the garnishee will be held the decisive factor in determining what state has the "superior interest," but in many others such priority may well be considered as not decisive.

Consider how this theory of "superior interest" might work in another hypothetical case.

\section{CASE II}

Armour Fertilizer Works sues Sanders in Illinois, serving him only constructively, but serving the Garnishee Company, a Connecticut insurance company that is lawfully transacting business in Mllinois, with an attachment in garnishment. As before, Sanders puts in no appearance and judgment is rendered against him by default. The Garnishee Company in its answer admits its indebtedness to Sanders, but sets up his claim of exemption under the Texas homestead statutes. Meanwhile Sanders has sued the insurance company, the Garnishee Company, in a state court in Texas, in which state the Garnishee Company is subject to service of process. While this Texas action is pending, and prior to disposition of the issues raised by the answer of the Garnishee Company 
in the Illinois action, the Garnishee Company files a bill in interpleader against Sanders and Armour Fertilizer Works in the United States District Court in the district in Texas in which Sanders resides. The amount due is paid into court, the Garnishee Company is discharged and injunctions issue restraining further prosecutions of the actions in the state courts of Illinois and Texas. What decree shall the court render in the interpleader suit?

Here, again, the court will not be primarily concerned with the rights of a garnishee since the Garnishee Company has paid its debt and obtained a complete discharge. As in the case before the United States Supreme Court and in Case I, Armour Fertilizer Works "asks nothing under any Texas law." Under the circumstances now supposed it has been brought into the United States District Court against its will and protest. By virtue of its garnishment action in Tlinois it claims the proceeds of the policy to the exclusion of Sanders. He, however, does ask something of Texas law-he claims the proceeds of the debt to him from the Garnishee Company as exempt from attachment or garnishment under Texas statute. Presumably the court here also is to "weigh the right or title of each claimant under the law of the state in which it arose, and determine which according to equity is the better." ${ }^{167}$ The fact that interpleader is brought in Texas does not necessarily mean that the court is to enforce exemptions given by Texas statutes. ${ }^{68}$

As has already been stated, the majority of the United States Supreme Court in the actual case of Sanders v. Armour Fertilizer Works found that Armour Fertilizer Works had, by service of the Tlinois attachment in garnishment, acquired a lien on the garnished debt, subject to defeasance if certain subsequent events happened. ${ }^{69}$ Becker v. Illinois Central $R$. $R$. $C o$. shows that one of such subsequent events would have been the recovery of a judgment in Texas by Sanders prior to the entry of a judgment against the garnishees in Tllinois.

In this second hypothetical case now under consideration Armour Fertilizer Works, following the reasoning of the majority in the United States Supreme Court, would contend (I) that the garnishment proceedings in Illinois gave it a "superior equity" to the proceeds of the debt that the Garnishee Company had paid into the federal court in Texas; (2) that had it secured an Illinois judgment against the Garnishee Com-

${ }^{66} 292$ U.S. I90, 200.

${ }_{67}$ Ibid. The court here quotes from the Circuit Court of Appeals opinion in 63 F. (2d) 902, 906 (C.C.A. $5^{\text {th }}$ r933).

${ }^{68}$ Ibid. $\quad{ }^{69}$ Id. at 203 . 
pany prior to any judgment against that company in Texas in favor of Sanders, its "lien" would have become absolute; and (3) that it would be inequitable to declare that because it had not been able, by reason of the injunction issued by the federal court in Texas, to get such final judgment in Illinois, Sanders had in some way become entitled to priority. On the other hand, Sanders would contend that $(I)$ under the law of Illinois as laid down in Becker v. Illinois Central R. R. Co., his "equity" would have prevailed had he secured a Texas judgment against the Garnishee Company before Armour Fertilizer Works secured a judgment against that company as garnishee in Tllinois; and (2) because he had been enjoined from securing such judgment, it would be inequitable to hold that in some way Armour Fertilizer Works had become entitled to priority.

Perhaps Sanders' claim would be denied. It is hard to see, however, why Armour Fertilizer Works would, on the reasoning of the majority of the United States Supreme Court, be entitled to prevail. Its claim is subject to the same objections as, so it is submitted, might be made to its claim in Case $I$. There is no need of restating them.

In this second hypothetical case the only real contest is between Sanders and his garnishing creditor. The federal court in Texas might well allow that creditor, Armour Fertilizer Works, to prevail. Illinois, the state enacting the garnishment statute, might be held to have an "interest" to be regarded as "superior" to that of Texas, the state enacting the homestead exemption statute that is involved. True, if this result is reached, the exemptions allowed Sanders by the law of his domicil, which is also the forum, are not secured to him. A federal court may, indeed, allow the same exemptions from execution and garnishment as are allowed under the law of the state in which such federal court sits; ${ }^{70}$ but in interpleader suits a court is properly less influenced by the law of the forum than in many other types of litigation. As a matter of fact the Supreme Court in Sanders v. Armour Fertilizer Works refused to enforce any claim of Sanders to exemption under Texas law. ${ }^{7 x}$ Neither the fact that Sanders is domiciled in Texas nor the fact that interpleader is brought in a federal court in that state is sufficient to require the court to hold that Sanders is entitled to the exemptions extended by the Texas homestead statutes. If the debt from Sanders to Armour Fertilizer Works had been contracted in Tllinois for goods sold and delivered to him there, the court might well consider that Mlinois had the "superior interest," especially if at the time

${ }^{70}$ I 7 Stat. 197 (1872); 36 Stat. 1167 (I9II); 28 U.S.C.A. $\$ 727$ (1928).

${ }^{7 x} 292$ U.S. I90, 200, where the court quotes from the opinion of the Circuit Court of Appeals in 63 F. (2d) 902, 906 (C.C.A. I933). 
the sale was made Sanders was residing in Illinois. The court might then feel that the fund in court should be awarded to Sanders' creditor. Moreover, exemptions from garnishment have been said to be only "remedial," i.e., a matter of procedure to be regulated by the law of the forum, not by the law of the principal debtor's domicil. ${ }^{72}$ In view of the decision in Sanders v. Armour Fertilizer Works it is doubtful whether Texas would be held to be the state with the "superior interest" merely because the premises insured were situated within its borders.

If this solution of the problem presented by the two hypothetical cases is followed, then the Garnishee Company is no longer an indifferent stakeholder. For example, in Case II, suppose that as soon as the Garnishee Company was garnished in Ilinois Sanders started suit in Texas against the Garnishee Company. That company would not be under any duty to take advantage of the Federal Interpleader Act. It could await the outcome of the two suits in Tllinois and Texas. If the Illinois court were the first to enter a judgment against it, Texas would be obliged to give full faith and credit to such judgment. If the Texas court were the first with judgment, Tllinois would, under Becker v. Illinois Central R. R. Co., give full faith and credit to the Texas judgment. If the Garnishee Company in some way, by pleading or otherwise, brought to the attention of each court the pendency of the suit in the other, and gave Sanders proper notice of the garnishment action, it would be secure from double liability in the United States. However, if the Garnishee Company took advantage of the Federal Interpleader Act to file interpleader in a federal court, it would cause the rights of the contesting claimants to be determined by a body of rules developed by federal courts as herein suggested. As will hereinafter be suggested, the chances are that the Garnishee Company, whenever possible, will choose to take advantage of the Federal Interpleader Act.

In Case $I$ if the Garnishee Company chooses to interplead under the

$7^{2}$ See Chicago, Rock Island \& Pacific Ry. Co. v. Sturm, I74 U.S. 710, 717-I8 (1899). Statutes may, of course, give a non-resident the same exemptions from garnishment as are allowed in the state of his residence. See, for example, III. Rev. Stat. 1935, c. 52, If 22 (wages earned and payable out of Illinois); Vt. Pub. L. r933, § I754 ("'nor shall a corporation be adjudged a trustee by reason of any money due from it to a person residing without the state for services rendered without the state, provided a like sum of money so due would be exempt from attachment by trustee process in the state where such person resides"). Some statutes exempt from garnishment wages earned and payable out of the state if the principal cause of action arose out of the state, unless the principal debtor is served personally in the garnishment suit. E.g., Ill. Rev. Stat. I935, c. 52, T 23; Iowa Code r935, § Ir769; Carroll's Ky. Stat. 1930, § rora; Tenn. Code I932, \$ 9429 . 
federal statute, rights of competing garnishing creditors are no longer settled by any race to priority of judgment in state courts. At the election of the Garnishee Company the rights of such competing creditors will now be a matter for adjudication according to a body of federal law built up by federal courts. State courts must still bow to such decisions as Harris v. Balk. Side by side with the rules imposed by the Supreme Court of the United States on the state courts in the matter of jurisdiction to garnish debts will grow up a body of jurisprudence administered only in federal courts in contests involving competing garnishing creditors brought into the federal courts at the election of supposedly indifferent stakeholders. In this new federal jurisprudence the courts should be able to avoid some of the questionable reasoning used in Chicago, Rock Island \& Pacific Ry. Co. v. Sturm and Harris v. Balk. ${ }^{73}$ There will be no need to discuss the "situs" of a debt for purposes of garnishment. There will be no need to resort to an "implied" agency in the garnishee creditor to sue the garnishee debtor as "agent" for the debtor-creditor. Out of place should be talk of "liens" and "inchoate liens" created by service of attachment in garnishment. In these cases the courts will have to consider the relationship of different states to the debt or debts alleged to exist between one or more principal creditors and a debtor-creditor and the relationship of those states to the debt from the debtor-creditor to the garnishee debtor. The relationship of some one state to these debts will be held the closest. That state will be held to have a "superior interest" entitling it to garnish the garnishee debtor at the suit of some one principal creditor. That "interest" will be "superior" to the "interest" of any other state to provide for the garnishment of the same debt by some other principal creditor. Or, in some cases like the second hypothetical, it may be that no state will have an "interest" to garnish "superior" to the "interest" of the state in which the debtor-creditor has sued the garnishee and the debtor-creditor will be allowed to recover in his own behalf.

The Federal Interpleader Act is broad in scope. It authorizes bills of interpleader

by any person, firm, corporation, association, or society .... having issued a note, bond, certificate, policy of insurance, or other instrument of the value or amount of $\$ 500$ or more, or providing for the delivery or payment or the loan of money or property at such amount or value, or being under any obligation written or unwritten to the amount of $\$ 500$ or more. 74

73 See Goodrich, Conflict of Laws I29-30 (1927); Beale, The Exercise of Jurisdiction in Rem to Compel Payment of a Debt, 27 Harv. L. Rev. I07, I2I-22 (I9I3).

${ }^{74} 49$ Stat. 1096 (1936); 28 U.S.C.A. § 4I (26) (1926) (as amended). 
The field for interpleader under this statute by a corporate garnishee is wide. The statute does not compel such a garnishee to take advantage of the privileges offered by it, but the benefits of so doing are so great that it is difficult to believe that a corporate garnishee will fail to make use of the privileges of the statute when opportunity offers. It is impossible to secure corresponding benefits in a state court due to the fact that the process of a state court does not run beyond the state boundaries. ${ }^{75}$ For example, suppose that a citizen of state S-I claims a "lien" on the proceeds of a \$rooo fire insurance policy by virtue of an attachment in garnishment served on the insurer in that state in a suit brought by the citizen of state S-I against a citizen of state S-2, the policyholder, in which the defendant was served only by publication and did not appear. Suppose, also, that a citizen of state S- 3 claims a "lien" on the same proceeds by virtue of an attachment in garnishment served on the insurer in that state in a suit brought by the citizen of state S-3 against the citizen of state S-2, the policyholder, in which the defendant was also served only by publication and did not appear. Suppose, further, that the citizen of state S-2, the policyholder, claims the proceeds on the theory that they are exempt from attachment in garnishment by virtue of the exemption statutes of state S-2, the state of his domicil and the state in which the property insured was located. The insurance company cannot force the citizens of states S-I and S-3 into a state court in state S-2 to interplead there with the citizen of state S-2. If there were no Federal Interpleader Act, the insurance company would be obliged to take care that it followed in each garnishment suit the course of conduct suggested for a garnishee in Harris v. Balk. It would be obliged to do so if it wished to be in a position to plead effectively a judgment entered against it as garnishee in bar of further prosecution of any action that the citizen of state S-2 might later institute against it on the policy as well as in bar of further prosecution of the garnishment suit in the other of the two states S-r and S-3. In practice the insurance company will often find itself vexed by two or more suits. Under the Federal Interpleader Act the insurer could interplead the different claimants in one suit in the federal district court of the district in which one (or more) of the claimants resides. ${ }^{76}$ By payment of the amount involved into court or by giving a bond conditioned upon its compliance with the future order or decree of the court with respect to the subject matter of the controversy ${ }^{77}$ the insurer could obtain relief

75 New York Life Insurance Co. v. Dunlevy, 24I U.S. 5 I9 (I916).

${ }^{76}{ }_{49}$ Stat. rog6 (I936); 28 U.S.C.A. § 4 I (26) (r926) (as amended).

77 Ibid. 
from double or multiple vexation. Further discussion of the benefits of the Federal Interpleader Act would be a work of supererogation in view of the able discussion of the statute elsewhere. ${ }^{78}$ With the stakeholder dismissed from further litigation in such cases as that which has just been briefly described the federal courts will have broad opportunities to develop sensible principles as to when one of several creditors of a debtor is entitled to priority in having his claim satisfied out of a debt due that debtor from a corporation that is doing business in more than one state. However, the cases will be many and the years long before these principles will be clearly enunciated.

${ }^{78}$ Chafee, The Federal Interpleader Act of 1936,45 Yale L. J. 963 ff., I16r ff. (r936). 